\title{
Paenibacillus zanthoxyli sp. nov., a novel nitrogen-fixing species isolated from the rhizosphere of Zanthoxylum simulans
}

\section{Correspondence Sanfeng Chen chensf@cau.edu.cn}

\author{
Yuchao Ma, ${ }^{1,2}$ Jian Zhang ${ }^{3}$ and Sanfeng Chen ${ }^{1,4}$ \\ ${ }^{1}$ National Key Laboratory for Agrobiotechnology, China Agricultural University, Beijing 100094, \\ People's Republic of China \\ ${ }^{2}$ College of Biological Science, China Agricultural University, Beijing 100094, People's Republic \\ of China \\ ${ }^{3}$ College of Life Science and Engineering, Qiqihar University, Qiqihar 161006, People's \\ Republic of China \\ ${ }^{4}$ Key Laboratory of Agro-Microbial and Application, China Agricultural University, Beijing \\ 100094, People's Republic of China
}

Ash et al. (1993) created the genus Paenibacillus from the genus Bacillus based on their 16S rRNA gene sequences. Members of the genus Paenibacillus are aerobic or facultatively anaerobic, rod-shaped, endospore-forming bacteria that are widely distributed in nature (Claus \& Berkeley, 1986; Slepecky \& Hemphill, 1991). Nitrogen fixation has been described in some species of Paenibacillus, such as Paenibacillus polymyxa (Grau \& Wilson, 1962), Paenibacillus

The GenBank/EMBL/DDBJ accession number for the 16S rRNA gene sequence of Paenibacillus zanthoxyli sp. nov. $\mathrm{JH}_{2}{ }^{\top}$ is DQ471303.

A more detailed phylogenetic tree that includes additional recognized species of the genus Paenibacillus is available as a supplementary figure in IJSEM Online. macerans (Witz et al., 1967), Paenibacillus azotofixans (Seldin et al., 1984), Paenibacillus peoriae (Elo et al., 2001), Paenibacillus graminis, Paenibacillus odorifer (Berge et al., 2002) and Paenibacillus brasilensis (von der Weid et al., 2002). It has been reported that $P$. azotofixans has the highest nitrogenase activity among these nitrogen-fixers (Achouak et al., 1999; Berge et al., 2002). P. azotofixans has been found in Brazilian and Hawaiian soils, but not in soils from temperate zones, while $P$. polymyxa has been isolated from various environments around the world on different plant roots (Berge et al., 2002).

Here we report the isolation of five novel strains from the rhizosphere of Zanthoxylum simulans (prickly-ash). The five novel strains have nitrogenase activities higher than that of 
$P$. azotofixans and their 16S rRNA gene sequences have a high level of similarity to that of $P$. azotofixans. The strains were identified as a novel species of the genus Paenibacillus based on phenotypic properties, 16S rRNA gene sequences, DNA G $+\mathrm{C}$ content, DNA-DNA hybridization, chemotaxonomic properties and nifH gene sequence.

The bacterial strains examined were isolated from the rhizosphere soil of prickly-ash planted in Beijing, China. A $1 \mathrm{~g}$ sample of soil was placed in $9 \mathrm{ml}$ sterile water and stirred for $50 \mathrm{~min}$. Aqueous portions $(100 \mu \mathrm{l})$ were heated at $80^{\circ} \mathrm{C}$ for $10 \mathrm{~min}$ and then spread on nitrogen-free medium in triplicate and incubated at $30^{\circ} \mathrm{C}$. The nitrogen-free medium used for the isolation of bacterial strains contained $\left(1^{-1}\right)$ : $20 \mathrm{~g}$ sucrose, $0.1 \mathrm{~g} \quad \mathrm{~K}_{2} \mathrm{HPO}_{4}, \quad 0.4 \mathrm{~g} \quad \mathrm{KH}_{2} \mathrm{PO}_{4}, \quad 0.2 \mathrm{~g}$ $\mathrm{MgSO}_{4} .7 \mathrm{H}_{2} \mathrm{O}, 0.1 \mathrm{~g} \mathrm{NaCl}, 0.01 \mathrm{~g} \mathrm{FeCl}_{3}$ and $0.002 \mathrm{~g}$ $\mathrm{Na}_{2} \mathrm{MoO}_{4}$. After 5 days incubation, five strains, designated JH8, JH29 ${ }^{\mathrm{T}}$, JH31, JT34 and JH95 were selected for further study.

To determine cell morphology, the five novel strains were grown on endospore-forming medium [0.07 \% yeast extract, $0.1 \%$ tryptone, $0.1 \%$ glucose, $0.02 \%\left(\mathrm{NH}_{4}\right)_{2} \mathrm{SO}_{4}, 0.02 \%$ $\mathrm{MgSO}_{4} .7 \mathrm{H}_{2} \mathrm{O}, 0.1 \% \mathrm{~K}_{2} \mathrm{HPO}_{4}(\mathrm{w} / \mathrm{v}), \mathrm{pH} 7.2$ ] for 72 h. Cell morphology was examined by light microscopy. Catalase activity was analysed by bubble formation in a $3 \%(\mathrm{w} / \mathrm{v})$ $\mathrm{H}_{2} \mathrm{O}_{2}$ solution. Hydrolysis of casein, gelatin and starch was determined as described by Cowan \& Steel (1965). Utilization of various substrates as carbon and energy sources was determined as described by Shirling \& Gottlieb (1966). Tolerance to $\mathrm{NaCl}$ was measured in a medium $[0.5 \%$ peptone, $0.3 \%(\mathrm{w} / \mathrm{v})$ beef extract] containing $\mathrm{NaCl}$ at concentrations of 3 and $5 \%(\mathrm{w} / \mathrm{v})$. Other physiological and biochemical tests were also performed using conventional methods (Priest et al., 1981; Rhodes-Roberts, 1981).

Analysis of cellular fatty acid contents was carried out as described by Komagata \& Suzuki (1987) using the Sherlock Identification System (MIDI).
To determine the nitrogen-fixing capability of the five strains, an assay for nitrogenase activity and PCR amplification of the nifH gene were carried out. A $324 \mathrm{bp}$ fragment of the nifH gene was isolated from the five novel strains as described by Ding et al. (2005). Nitrogenase activity was determined by the acetylene-reduction assay method (Berge et al., 2002).

Chromosomal DNA was extracted and purified according to standard method (Sambrook et al., 1989). The $16 \mathrm{~S}$ rRNA gene sequence was amplified as described by Yanagi \& Yamasato (1993) and sequenced (Ding et al., 2005). Sequences were aligned using CLUSTAL_X software (Thompson et al., 1997). Evolutionary distances were calculated using the DNADIST program from the TREECONW software package. A phylogenetic tree was generated by the neighbour-joining method using the TREECONW software package (Van der Peer \& De Wachter, 1994).

DNA-DNA hybridization and DNA G $+\mathrm{C}$ content were determined as described by De Ley et al. (1970).

The nearly complete $16 \mathrm{~S}$ rRNA gene sequences of the five novel strains were compared with sequences held in GenBank. This analysis indicated that the novel strains are phylogenetically related to members of the genus Paenibacillus. A neighbour-joining phylogenetic tree showing the position of the novel strains in relation to some other Paenibacillus species is shown in Fig. 1. A more detailed phylogenetic tree that includes additional recognized species of the genus Paenibacillus is available as Supplementary Fig. S1 in IJSEM Online. The five novel strains showed high levels of $16 \mathrm{~S}$ rRNA gene sequence similarity with $P$. azotofixans ATCC $35681^{\mathrm{T}}(97.81-98.5 \%)$ and Paenibacillus stellifer DSM $14472^{\mathrm{T}}$ (95.39-96.25\%). Levels of 16S rRNA gene sequence similarity between the five novel strains and other species of Paenibacillus were less than $95.0 \%$. Levels of $16 \mathrm{~S}$ rRNA gene sequence similarity among the five novel strains were more than $98.0 \%$.

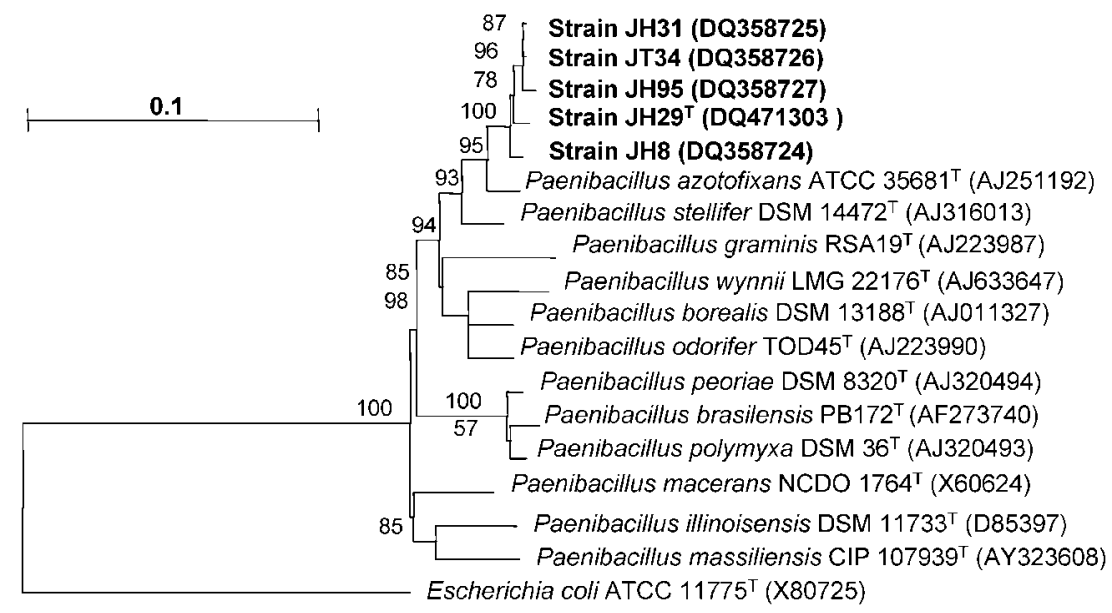

Fig. 1. Phylogenetic tree based on neighbourjoining analysis of the 16S rRNA gene sequence of $P$. zanthoxyli sp. nov. compared with other Paenibacillus species. Escherichia coli was used as an outgroup. Bootstrap analyses were performed with 1000 cycles. Only bootstrap values $>50 \%$ are shown at the branch points. Bar, 0.1 substitutions per nucleotide position. 
Table 1. Phenotypic characteristics of $P$. zanthoxyli sp. nov. and other nitrogen-fixing Paenibacillus species

Taxa: 1, P. zanthoxyli sp. nov. (five strains tested); 2, P. azotofixans ATCC $35681^{\mathrm{T}}$; 3, P. polymyxa ATCC $842^{\mathrm{T}}$; 4, P. macerans ATCC $8244^{\mathrm{T}}$; 5, P. odorifer TOD45 ${ }^{\mathrm{T}}$; 6, P. graminis RSA $19^{\mathrm{T}}$; 7, P. stellifer DSM $14472^{\mathrm{T}} ; 8$, P. brasilensis DSM $14914^{\mathrm{T}}$; 9, P. peoriae DSM $8320^{\mathrm{T}}$. Data for taxa 5, 6, 8 and 9 are from von der Weid et al. (2002). Data for taxon 7 are from Suominen et al. (2003). +, Positive; -, negative; V, variable; ND, not determined.

\begin{tabular}{|c|c|c|c|c|c|c|c|c|c|}
\hline Characteristic & 1 & 2 & 3 & 4 & 5 & 6 & 7 & 8 & 9 \\
\hline Optimum growth temp. $\left({ }^{\circ} \mathrm{C}\right)$ & 30 & 30 & 30 & 30 & 30 & 30 & 28 & 30 & 30 \\
\hline Growth with lysozyme $(0.001 \%)$ & - & - & - & + & + & - & $\mathrm{ND}$ & + & + \\
\hline Nitrate reduction & + & + & + & + & + & + & - & + & + \\
\hline Production of dextrin & - & - & - & + & - & - & + & - & - \\
\hline Gelatin & - & - & - & - & - & - & ND & $\mathrm{V}$ & + \\
\hline Starch & - & - & - & - & - & - & + & + & + \\
\hline \multicolumn{10}{|l|}{ Acid produced from: } \\
\hline L-Aspartate & - & + & + & + & + & + & - & ND & ND \\
\hline Fructose & - & - & - & - & - & - & + & + & - \\
\hline Sodium citrate & - & - & - & - & - & - & - & + & + \\
\hline Sodium succinate & - & - & - & + & - & - & - & + & + \\
\hline D-Sorbitol & - & - & + & + & - & - & - & - & + \\
\hline Sucrose & - & - & + & + & + & - & + & $\mathrm{ND}$ & + \\
\hline D-Xylose & - & - & - & - & - & - & + & - & + \\
\hline DNA G $+\mathrm{C}(\mathrm{mol} \%)$ & $52.3-54.4$ & 50.7 & $43-46$ & $49-51$ & 44 & 52.1 & 55.6 & $\mathrm{ND}$ & $45-47$ \\
\hline
\end{tabular}

The five novel strains are facultatively anaerobic, Grampositive, motile, straight rods $(0.35-0.4 \times 4.0-4.8 \mu \mathrm{m})$. They produce ellipsoidal or oval spores that are located subterminally or centrally in swollen sporangia. Colonies of the strains on nutrient agar are circular, convex and glossy with entire margins. The phenotypic characteristics of the novel strains and reference Paenibacillus species are presented in
Table 1. The five novel strains were found to have physiological properties that enabled them to be distinguished from these recognized Paenibacillus species. The DNA G $+\mathrm{C}$ contents of strains $\mathrm{JH} 29, \mathrm{JH} 8, \mathrm{JH} 31, \mathrm{JH} 34$ and $\mathrm{JH} 95$ were 52.3-54.4 mol\% (Table 1), which are in the range characteristic of recognized Paenibacillus species (Shida et al., 1997).

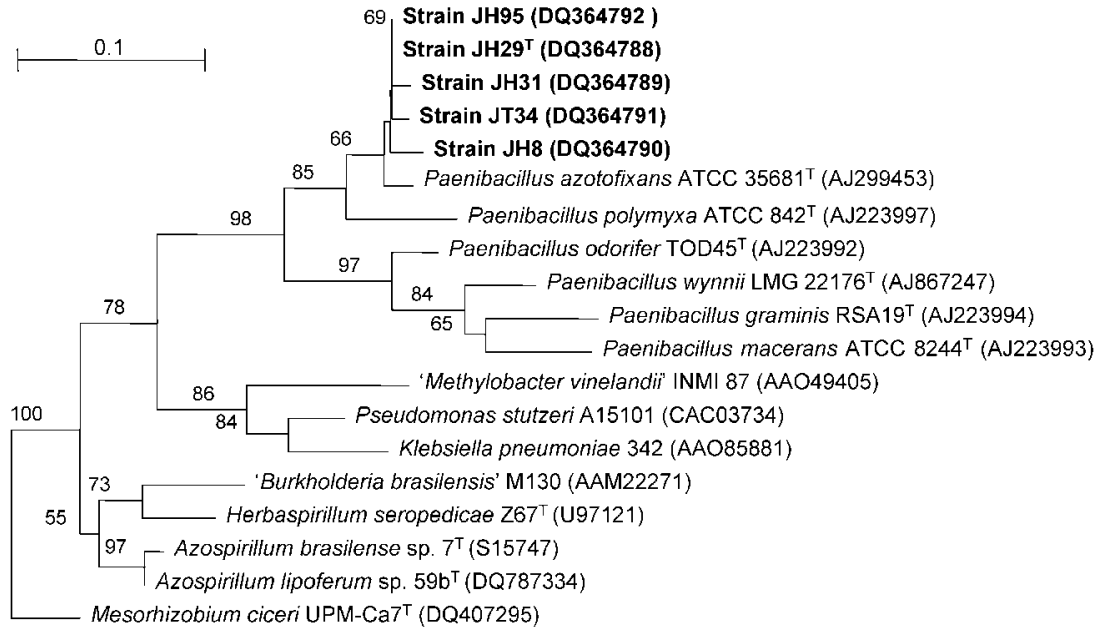

Fig. 2. Phylogenetic tree based on partial nifH gene sequences, showing the position of the five novel strains in relation to other bacterial species from the GenBank database. Bootstrap analyses were performed with 1000 cycles. Only bootstrap values $>50 \%$ are shown at the branch points. Bar, 0.1 substitutions per nucleotide position. 
PCR amplification demonstrated that all five novel strains possess the nifH gene. Phylogenetic analysis based on nifH sequences revealed that the five strains clustered together with species of the genus Paenibacillus (Fig. 2). The five novel strains showed high levels of nifH gene sequence similarity with P. azotofixans ATCC $35681^{\mathrm{T}}(97.20-98.15 \%)$, P. polymyxa (93.18-95.45\%) and P. odorifer (88.79\%). Levels of nif $H$ gene sequence similarity among the five novel strains were $97.22-100 \%$.

The nitrogenase activity of the five novel isolates and $P$. azotofixans, $P$. polymyxa, $P$. macerans, $P$. odorifer and $P$. graminis was also tested by the acetylene-reduction assay method (Berge et al., 2002). As shown in Table 2, all of the novel strains exhibited significant nitrogenase activity.

DNA-DNA hybridization tests were performed to determine the genomic relatedness between the five novel strains and the type strain of $P$. azotofixans. DNA-DNA relatedness between the novel strains and P. azotofixans ATCC $35681^{\mathrm{T}}$ was $45.50-47.45 \%$ and among the five novel strains the relatedness value was $95.8-99.6 \%$.

The cellular fatty acid profile of one of the novel isolates, $\mathrm{JH} 29^{\mathrm{T}}$, was determined together with those of $P$. azotofixans ATCC $35681^{\mathrm{T}}$, P. stellifer DSM $4472^{\mathrm{T}}, P$. polymyxa DSM $36^{\mathrm{T}}$ and P. macerans ATCC $8244^{\mathrm{T}}$ (Table 3). Anteiso-branched $\mathrm{C}_{15: 0}$, the major fatty acid characteristic for the genus Paenibacillus, was also the major fatty acid component $(32.19 \%)$ of strain $\mathrm{JH} 29^{\mathrm{T}}$.

In conclusion, on the basis of phenotypic properties, $16 \mathrm{~S}$ rRNA gene sequences, DNA G + C content, DNA-DNA hybridization, chemotaxonomic properties and nifH gene sequence, the five novel strains form a very homogeneous group which is different from other related species within the genus Paenibacillus. Therefore, we propose that they represent a novel species of the genus Paenibacillus, for

Table 2. Nitrogenase activity of the five novel strains and nitrogen-fixing Paenibacillus reference strains

Values are \pm standard deviation.

\begin{tabular}{|c|c|}
\hline Strain & $\begin{array}{c}\text { Activity }\left[\text { nmol } \mathrm{C}_{2} \mathrm{H}_{2}\right. \\
\left.\left(\mathrm{mg}_{\text {protein }}^{-1}\right)\right]\end{array}$ \\
\hline P. azotofixans ATCC $35681^{\mathrm{T}}$ & $2256.8 \pm 46.9$ \\
\hline P. polymyxa ATCC $842^{\mathrm{T}}$ & $3.2 \pm 0.55$ \\
\hline P. macerans ATCC $8244^{\mathrm{T}}$ & $2.48 \pm 0.2$ \\
\hline P. odorifer TOD $45^{\mathrm{T}}$ & $37.62 \pm 18.9$ \\
\hline P. graminis $\mathrm{RSA} 19^{\mathrm{T}}$ & $272.9 \pm 7.9$ \\
\hline \multicolumn{2}{|l|}{ P. zanthoxyli sp. nov. } \\
\hline $\mathrm{JH} 29^{\mathrm{T}}$ & $6282.4 \pm 107.97$ \\
\hline JH8 & $2815.7 \pm 211.4$ \\
\hline JH31 & $2702.2 \pm 81.2$ \\
\hline JT34 & $2526.6 \pm 24.2$ \\
\hline JH95 & $1872.1 \pm 184.3$ \\
\hline
\end{tabular}

Table 3. Cellular fatty acid profiles (\%) of $P$. zanthoxyli sp. nov. $\mathrm{JH}_{29^{\top}}$ and closely related Paenibacillus species

Strains: 1, P. zanthoxyli sp. nov. $\mathrm{JH}_{2} 9^{\mathrm{T}} ; 2$, P. azotofixans ATCC $35681^{\mathrm{T}}$ (Yoon et al., 2003); 3, P. stellifer DSM $14472^{\mathrm{T}}$ (Suominen et al., 2003); 4, P. polymyxa DSM $36^{\mathrm{T}}$ (Yoon et al., 2003); 5, P. macerans ATCC $8244^{\mathrm{T}}$ (Elo et al., 2001). NR, Not reported. Only selected fatty acids of strain $\mathrm{JH} 29^{\mathrm{T}}$ are presented for comparison.

\begin{tabular}{|lrrrrr|}
\hline Fatty acid & $\mathbf{1}$ & $\mathbf{2}$ & $\mathbf{3}$ & $\mathbf{4}$ & $\mathbf{5}$ \\
\hline Saturated straight-chain & & & & & \\
$\mathrm{C}_{14: 0}$ & 4.87 & 5.0 & 0.7 & 5.0 & 3.7 \\
$\mathrm{C}_{15: 0}$ & 2.07 & 2.2 & 0.5 & 3.4 & 0.5 \\
$\mathrm{C}_{16: 0}$ & 12.83 & 15.5 & 9.1 & 20.5 & 17.9 \\
$\mathrm{C}_{18: 0}$ & 6.74 & 0.3 & 1.1 & 0.3 & $\mathrm{NR}$ \\
Saturated iso-branched & & & & & \\
$\mathrm{C}_{14: 0}$ & 3.99 & 4.7 & 0.6 & 4.7 & 1.8 \\
$\mathrm{C}_{15: 0}$ & 1.51 & 8.7 & 5.5 & 8.7 & 2.6 \\
$\mathrm{C}_{16: 0}$ & 14.85 & 5.3 & 7.7 & $\mathrm{NR}$ & 17.1 \\
$\mathrm{C}_{17: 0}$ & 0.61 & 1.1 & 7.0 & $\mathrm{NR}$ & 4.1 \\
Saturated anteiso-branched & & & & & \\
$\mathrm{C}_{13: 0}$ & 0.49 & $\mathrm{NR}$ & $\mathrm{NR}$ & 1.8 & $<0.2$ \\
$\mathrm{C}_{15: 0}$ & 32.19 & 45.4 & 49.9 & 45.5 & 34.5 \\
$\mathrm{C}_{17: 0}$ & 3.89 & 2.1 & 16.7 & 2.1 & 16.1 \\
Unsaturated $^{*}$ & & & & & \\
$\mathrm{C}_{18: 1} \omega 5 c$ & 2.02 & $\mathrm{NR}$ & $\mathrm{NR}$ & 1.8 & $\mathrm{NR}$ \\
$\mathrm{C}_{18: 1} \omega 7 c$ & 1.78 & $\mathrm{NR}$ & $\mathrm{NR}$ & $\mathrm{NR}$ & $\mathrm{NR}$ \\
$\mathrm{C}_{18: 1} \omega 9 c$ & 1.51 & $<0.2$ & $<0.2$ & $<0.2$ & $<0.2$ \\
\hline
\end{tabular}

*The position of the double bond can be located by counting from the methyl $(\omega)$ end of the carbon chain. A cis isomer is indicated by the suffix $c$.

which the name of Paenibacillus zanthoxyli sp. nov. is proposed.

\section{Description of Paenibacillus zanthoxyli sp. nov.}

Paenibacillus zanthoxyli (zan'th.ox.y.li. N.L. gen. n. zanthoxyli of Zanthoxylum, referring to the plant Zanthoxylum simulans, the source of the rhizosphere soil from which the type strain was isolated).

Gram-positive, facultatively anaerobic, motile, straight rods $(0.35-0.4 \times 4.0-4.8 \mu \mathrm{m})$. Oval or ellipsoidal endospore located subterminally or centrally in swollen sporangia. Colonies on nutrient agar are circular, convex and glossy with entire margins. Growth occurs at $\mathrm{pH} 4.2-10.0$ and at $4-37^{\circ} \mathrm{C}$. Growth occurs in $3 \%(\mathrm{w} / \mathrm{v}) \mathrm{NaCl}$, but not in $0.001 \%(\mathrm{w} / \mathrm{v})$ lysozyme. Catalase activity is positive and oxidase activity is negative. Voges-Proskauer and methylred reactions are positive. Nitrogen fixation is detected by the presence of the nifH gene and acetylene reduction in all strains. Acid and gas are not produced from glucose, sucrose, lactose, fructose, glycerol, xylose, maltose, D-sorbitol, sodium succinate, sodium citrate, glycine or L-aspartate. Gelatin, casein and starch are not hydrolysed. The major cellular fatty acids of the type strain, $\mathrm{JH} 29^{\mathrm{T}}$, are 
anteiso- $\mathrm{C}_{15: 0}$, iso- $\mathrm{C}_{16: 0}$ and $\mathrm{C}_{16: 0}$. The DNA G $+\mathrm{C}$ content of the type strain is $53.2 \mathrm{~mol} \%$.

The type strain, $\mathrm{JH} 29^{\mathrm{T}}\left(=\mathrm{CCBAU} 10243^{\mathrm{T}}=\mathrm{DSM} 18202^{\mathrm{T}}\right)$, was isolated from the rhizosphere soil of Zanthoxylum simulans planted in Beijing, China.

\section{Acknowledgements}

We are grateful to Dr Berge for the generous gifts of the P. polymyxa and P. macerans strains. We thank Professor Tianshen Tao in the Chinese Academy of Agricultural Sciences for technical guidance. This work was supported by the Chinese National "973" Project (Grant No. 001CB108904).

\section{References}

Achouak, W., Normand, P. \& Heulin, T. (1999). Comparative phylogeny of rrs and nifH genes in the Bacillaceae. Int J Syst Bacteriol 49, 961-967.

Ash, C., Priest, F. G. \& Collins, M. D. (1993). Molecular identification of rRNA group 3 bacilli (Ash, Farrow, Wallbanks and Collins) using a PCR probe test. Proposal for the creation of a new genus Paenibacillus. Antonie van Leeuwenhoek 64, 253-260.

Berge, O., Guinebretière, M. H., Achouak, W., Normand, P. \& Heulin, T. (2002). Paenibacillus graminis sp. nov. and Paenibacillus odorifer sp. nov., isolated from plant roots, soil and food. Int J Syst Evol Microbiol 52, 607-616.

Claus, D. \& Berkeley, R. C. W. (1986). Genus Bacillus Cohn 1872, $174^{\mathrm{AL}}$. In Bergey's Manual of Systematic Bacteriology, vol. 2, pp. 1105-1139. Edited by P. H. A. Sneath, N. S. Mair, M. E. Sharpe \& J. G. Holt. Baltimore: Williams \& Wilkins.

Cowan, S. T. \& Steel, K. J. (1965). Manual for the Identification of Medical Bacteria. London: Cambridge University Press.

De Ley, J., Cattoir, H. \& Reynaerts, A. (1970). The quantitative measurement of DNA hybridization from renaturation rates. Eur J Biochem 12, 133-142.

Ding, Y., Wang, J., Liu, Y. \& Chen, S. (2005). Isolation and identification of nitrogen-fixing bacilli from plant rhizospheres in Beijing region. J Appl Microbiol 99, 1271-1281.

Elo, S., Suominen, I., Kämpfer, P., Juhanoja, J., Salkinoja-Salonen, M. \& Haahtela, K. (2001). Paenibacillus borealis sp. nov., a nitrogenfixing species isolated from spruce forest humus in Finland. Int J Syst Evol Microbiol 51, 535-545.

Grau, F. H. \& Wilson, P. W. (1962). Physiology of nitrogen-fixation by Bacillus polymyxa. J Bacteriol 83, 490-496.

Komagata, K. \& Suzuki, K. (1987). Lipid and cell wall analysis in bacterial systematics. Methods Microbiol 19, 161-207.

Priest, F. G., Goodfellow, M. \& Todd, C. (1981). The genus Bacillus: a numerical analysis. In The Aerobic Endospore-forming Bacteria
Classification and Identification, pp. 91-103. Edited by R. C. W. Berkeley \& M. Goodfellow. London: Academic Press.

Rhodes-Roberts, M. (1981). The taxonomy of some nitrogen-fixing Bacillus species with special reference to nitrogen fixation. In The Aerobic Endospore-Forming Bacteria. Classification and Identification, pp. 315-335. Edited by R. C. W. Berkeley \& M. Goodfellow. London: Academic Press.

Sambrook, J., Fritsch, E. F. \& Maniatis, T. (1989). Molecular Cloning: a Laboratory Manual, 2nd edn. Cold Spring Harbor, NY: Cold Spring Harbor Laboratory.

Seldin, L., van Elsas, J. D. \& Penido, E. G. C. (1984). Bacillus azotofixans sp. nov., a nitrogen-fixing species from Brazilian soils and grass roots. Int J Syst Bacteriol 34, 451-456.

Shida, O., Takagi, H., Kadowaki, K., Nakamura, L. K. \& Komagata, K. (1997). Transfer of Bacillus alginolyticus, Bacillus chondroitinus, Bacillus curdlanolyticus, Bacillus glucanolyticus, Bacillus kobensis, and Bacillus thiaminolyticus to the genus Paenibacillus and emended description of the genus Paenibacillus. Int J Syst Bacteriol 47, 289-298.

Shirling, E. B. \& Gottlieb, D. (1966). Methods for characterization of Streptomyces species. Int J Syst Bacteriol 16, 313-340.

Slepecky, E. B. \& Hemphill, E. (1991). The genus Bacillus nonmedical. In The Prokaryotes, vol. 2, pp. 1663-1696. Edited by A. Balows, H. G. Truper, M. Dworkin, W. Harder \& K.-H. Schleifer. New York: Springer.

Suominen, I., Spröer, C., Kämpfer, P., Rainey, F. A., Lounatmaa, K. \& Salkinoja-Salonen, M. S. (2003). Paenibacillus stellifer sp. nov., a cyclodextrin-producing species isolated from paperboard. Int J Syst Evol Microbiol 53, 1369-1374.

Thompson, J. D., Gibson, T. J., Plewniak, F., Jeanmougin, F. \& Higgins, D. G. (1997). The CLUSTAL_X windows interface: flexible strategies for multiple sequence alignment aided by quality analysis tools. Nucleic Acids Res 25, 4876-4882.

Van der Peer, Y. \& de Wachter, R. (1994). TREECON for Windows: a software package for construction and drawing of evolutionary trees for the Microsoft Windows environment. Comput Appl Biosci 10, $569-570$.

von der Weid, I., Duarte, G. F., van Elsas, J. D. \& Seldin, L. (2002). Paenibacillus brasilensis sp. nov., a novel nitrogen-fixing species isolated from the maize rhizosphere in Brazil. Int J Syst Evol Microbiol 52, 2147-2153.

Witz, D. F., Detroy, R. W. \& Wilson, P. W. (1967). Nitrogen fixation by growing cells and cell-free extracts of the Bacillaceae. Arch Mikrobiol 55, 369-381.

Yanagi, M. \& Yamasato, K. (1993). Phylogenetic analysis of the family Rhizobiaceae and related bacteria by sequencing of $16 \mathrm{~S}$ rRNA gene using PCR and DNA sequencer. FEMS Microbiol Lett 107, $115-120$.

Yoon, J. H., Oh, H. M., Yoon, B. D., Kang, K. H. \& Park, Y. H. (2003). Paenibacillus kribbensis sp. nov. and Paenibacillus terrae sp. nov., bioflocculants for efficient harvesting of algal cells. Int J Syst Evol Microbiol 53, 295-301. 